\title{
TO INHERIT THE EARTH
}

John French*

WRIGHT, Angus e WOLFORD, Wendy. To Inherit the Earth: The Landless Movement and the Struggle for a New Brazil. Oakland, CA: Food First Books, 2003

À medida que o Brasil entrava no Terceiro Milênio, o perfil político e socioeconômico do quinto maior país do mundo mudou dramaticamente se comparado a 1985, quando os militares retornaram aos seus quartéis, após 21 anos de ditadura. Enquanto a constituição visionária de 1988 agregava muito sonhos oriundos das mobilizações em massa dos anos 70, a nova trajetória das decisões políticas da República estava sendo mais decisivamente moldada pelas reformas do mercado neoliberal da globalização liderada por Washington. Conjuntamente, a rápida expansão e modernização do agronegócio brasileiro tornaram o país uma potência mundial exportadora de novos e velhos produtos agrícolas (276-77). Para alguns, o Brasil cada vez mais urbano da década de 1990 parecia anos-luz longe do mundo rural 'tradicional' advindo do legado da agricultura de plantation e da escravidão africana (que acabou apenas em 1888).

Poucos teriam previsto na década passada que a reforma agrária teria alcançado uma proeminência política sem precedente ao final da década de 1990. Apesar da administração presidencial de FHC não ser simpática a distribuição de terras como uma resposta à pobreza rural distribuiu, depois do infeliz massacre de 1996, terras para seiscentas mil famílias antes de deixar o poder em 2002 (Bruno Konder Comparato, "A Ação Política do MST," São Paulo em Perspectiva [São Paulo: SEADE, 2001]). A decisão de fazê-la, apesar de suas reservas, foi acelerada pela militância, por ímpeto e força de uma organização radical conhecida como Movimento dos Trabalhadores Rurais Sem Terra, ou MST. Com mais de um milhão de membros, o MST já "enfrentou a polícia, os militares, e grupos de atiradores. Sofreram condenações, espancamentos, e, algumas vezes, assassinatos. Ao invés de esperar o governo cumprir suas promessas antigas", eles repetidamente organizaram ocupações em massa de terras reivindicadas por proprietários ricos até que o governo aceitasse suas demandas (trezentas e cinquenta mil famílias vivem

\footnotetext{
* Tradução: Laura Candian Fraccaro.
} 
agora nos assentamentos do MST) (xiii). A trajetória do movimento é ainda mais marcante num mundo globalizado cada vez menos simpático à reforma socializante, muito meno à revolução que serve como horizonte do radicalismo do MST $(307,312)$.

Fundado em 1984 como um dos muitos grupos atuantes no campo, o MST emergiu nos meados de 1990 como a nova voz mais efetiva do protesto subalterno do país. O crescimento da organização para o nível nacional foi baseado na radicalização das táticas e estratégias de luta agrária, num país onde centenas já foram mortos em lutas pela terra, mesmo quando conduzido de forma menos agressiva. Enquanto injetava uma nova audácia e ambição, o MST era também marcado por uma forma de organização coesa e um senso acurado de como fazer com que ocupações dramáticas de terras alcançassem sucesso sob adversas condições políticas e econômicas. Em todo momento, o MST foi agressiva e persistente "até o ponto em que bateu de frente com pessoas que se consideravam apoiadores do movimento. Retrospectivamente, parecia improvável que qualquer movimento menos agressivo, menos persistente, e menos independente dos seus aliados poderia finalmente mudar as regras do jogo em termos de reforma agrária no Brasil" (xx). Como uma bem sucedida e "disciplinada organização política a favor da reforma agrária"(242), o MST provou ter uma poderosa atração dentro do Brasil, e conseguiu uma audiência internacional através de sua participação nos movimentos contra a globalização de Gênova a Cancun.

Para aqueles estrangeiros que conhecem pouco sobre o MST, esse maravilhoso e elucidativo livro de Angus Wright e Wendy Wolford oferece uma introdução com informações densas, mas de fácil leitura sobre o papel do movimento na lutas contemporâneas pela terra. Como uma colaboração entre Brasilianistas de diferentes disciplinas e gerações, To Inherit the Earth traz efetivamente a admirável criatividade e dinamismo do MST para um público não familiarizado com o Brasil, sua história, ou a diversidade do povo rural com que o MST se engajou produtivamente. Os autores traçam com pesquisa e familiaridade o MST no sul do país, principalmente, os estados de Santa Catarina e Rio Grande do Sul, onde nasceu o movimento; nos dois estado do nordeste, Bahia e Pernambuco; e no norte do Pará na região da Amazônia. Depois de fornecerem informações sobre a desigualdade política nesse país de 180 milhões de pessoas, os autores explicam o que eles chamam a "geografia da história", já que "o MST não escapou das influências geográficas das regiões extremamente separadas pela distância e diversidade das 
atividades econômicas, históricas e culturais. Em cada região o movimento se deparou com diferentes desafios; teve que trabalhar de diferentes maneiras e obteve diferentes resultados" (xxiii). O cerne do livro e o seu maior propósito são encontrados no três capítulos focados regionalmente. Cada um deles agrega diferentes problemáticas: Rio Grande do Sul (o regime militar, mobilização em massa, e luta pela democracia), Pernambuco (a herança da escravidão, agricultura de plantação, e subdesenvolvimento), e Pará (expansão dramática na fronteira, dinamismo econômico, e controvérsias ambientais).

Com sua mensagem única, organização coesa, e ideologia, o MST contribui para uma representação externa de si mesmo, tanto por seus oponentes quanto por seus aliados, que the atribuem (ou ratificam) um falso grau de coerência e solidez. Essa obra, por contraste, enfatiza os povos rurais, em suas especificidades, com os quais a organização trabalha. A história é contada, não tanto de cima do MST, mas dentro de cada um dos cinco assentamentos estudados, enfocando como seus membros se ligam com seus respectivos mundos locais (uma particular ênfase nos capítulos 2 e 3). O livro é jornalístico no melhor sentido, com descrições atraentes da terra e das pessoas, incluindo interessantes perfis dos principais líderes, atividades, e seguidores (algum deles menos integrados no projeto do MST). Por várias vezes, os autores oferecem retratos individuais completos que são analisados densamente, como, por exemplo, de um dedicado ativista do MST, Antonio, que eventualmente chega a sair do movimento para trabalhar para o prefeito local (157-69). Sua história é parte de uma explicação sofisticada para entender alguns dos constrangimentos do sucesso do MST, especialmente da Zona da Mata. De antiga cultura do açúcar, essa região de Pernambuco é colocada a parte em um capítulo interessante pelo jovem geógrafo Wolford. Ambos os capítulos 2 e 3 também ilustram como as divergências no processo de ocupação até o assentamento se relacionam com os desafios que o MST enfrenta depois da vitória: formar comunidades que refletam um comprometimento em fazer continuar a crescer consciência, a participação, e militância por seus membros já assentados.

Apesar do sucesso do MST ser creditado por muitos à ação direta em massa e à militância anti-estatal, Wright e Wolford dão igual importância a sofisticada estratégia política e legal da organização. Em particular, apresentam ao leitor leigo o argumento, prevalente na literatura acadêmica especializada, que o MST, com sucesso, utilizou "o velho paradoxo da lei da terra" no Brasil (xxii), o qual supõe a função social da propriedade e do respeto pelo princípio de seu "uso efetivo" como base pelo direito à terra (desta maneira 
facilitando a tomada da terra e a ocupação). Dado títulos duvidosos, o MST é especialista em disputar a história dos títulos de terrenos caracterizado, em muitos casos, por uma enorme carga de fraudes sob fraudes, enquanto avançam a proposição mais ampla do que a mal "distribuição de propriedade, e a lei sobre a qual é baseada, constituem uma grave injustiça social." Para muitos advogados, juízes, e políticos (24), desobediência civil é, desta maneira, um meio de se atingir "um dever social positivo."

No entanto, ressaltam que uma estratégia legal sozinha não garantiria vitória numa luta pela terra, a qual requer não apenas ação direta mas também "estratégias [políticas], táticas e alianças bem testadas." (242) Como parte da Esquerda Brasileira, o MST e suas rivais (sindicatos, ONGs, CPTs) funcionam dentro de uma teia de alianças de classes sociais, coalizões, e redes. $(53,186,67)$. O MST, como a literatura brasileira tem apresentado, mostra um talento especial em liderar eventos dramáticos na mídia, enquanto os ligam ao sentimentos morais das classes sociais urbanas já distantes do campo. Como Wright e Woldford observam, o sucesso do MST é um saudável produto de um país que é cada vez mais democrático em seu futuro e sentimento, como demonstrado pela eleição e re-eleição como Presidente de Luís Inácio Lula da Silva, um antigo líder sindical que presenciou a fundação do MST em 1984.

O público de língua inglesa finalmente possui uma quantidade de material razoável sobre a história "notável e complicada" do MST, que inclui "tanto vitórias e derrotas, soluções brilhantes, e contínuos dilemas" (xxvi). O foco na base do movimento da obra To Inherit the Eart, sua contribuição mais importante, pode ser complementada por uma versão jornalística de 2002 que enfoca de modo mais acentuado na prática e ideologia do MST como uma organização radical de esquerda: Sue Branford e Jan Rocha, Cutting the Wire: The Story of the Landless Movement in Brazil (London:Latin American Bureau, 2002). Também existe um documentário de 41 minutos dirigido, Strong Roots por Maria Luisa Mendonça, (New York: Cinema Guild, Inc., 2001). Quando combinada com a obra excelente sobre sindicalismo rural de Biorn Maybury-Lewis, The Politics of the Possible: The Brazilian Rural Workers' Trade Union Movement, 1964 -1985 (Philadelphia:Temple University Press, 1994), leitores interessados tem acesso a um retrato compreensível da frente rural de luta por "um sistema alternativo de política [e economia], uma maneira diferente de organizar a luta por 'direito a ter direitos'" (vii), uma importante dimensão do que vem acontecendo na trajetória única brasileira nos última metade do século. 